\title{
ZS Research Square \\ Aminolytic Depolymerisation of Polyethylene Terephthalate Wastes using Sn doped ZnO Nanoparticles
}

\author{
Viswanathan Vinitha \\ Pachaiyappa's College \\ Mani Preeyangha \\ SRMIST: SRM Institute of Science and Technology \\ Murugan Anbarasu \\ Pachaiyappa's College \\ Gopal Jeya \\ Pachaiyappa's College \\ Neppolian Bernaurdshaw \\ SRMIST: SRM Institute of Science and Technology \\ Vajiravelu Sivamurugan ( $\nabla$ sivaatnus@gmail.com ) \\ Pachaiyappa's College https://orcid.org/0000-0002-9295-2118
}

\section{Research Article}

Keywords: Aminolysis, PET waste, Chemical recycling, Nanocatalysis, ZnO, Doping

Posted Date: December 17th, 2021

DOI: https://doi.org/10.21203/rs.3.rs-1156910/v1

License: (c) (i) This work is licensed under a Creative Commons Attribution 4.0 International License. Read Full License 


\section{Abstract}

Poly(ethylene terephthalate) (PET) is one of the most consumed polymers because of its excellent thermal and mechanical properties. By increasing in PET production and since the disposal of PET waste has growing to be a major global environmental issue each year. Chemical recycling is a most successful method to achieve circular economy in the PET utilizing industries. Current research work aims to complete depolymerization of waste PET from soft drink bottles by the aminolysis method to produce bis (2-hydroxy ethylene) terephthalamide (BHETA) in the presence of Sn doped $\mathrm{ZnO}$. To evaluate catalytic activity, pure and $\mathrm{Sn}^{2+}$ doped $\mathrm{ZnO}$ nanoparticles prepared using different $\mathrm{Sn}^{2+}$ molar ratios at $0.5,1.0$ and $2.0 \mathrm{~mol} \%$ and calcined at $500{ }^{\circ} \mathrm{C}$ for $1 \mathrm{~h}$. The synthesized catalysts characterised using FT-IR, XRD, and UV-vis spectroscopy. The surface morphology and percentage doping obtained from SEM and SEM-EDS, respectively. We have observed a reduction in optical band gap and crystallite size of ZnO due to tin doping. Aminolytic depolymerization of PET waste using ethanolamine promoted by Sn doped ZnO effectively under conventional thermal method. Increase in the yield of the BHETA observed with respect to increasing doping percentage of Sn and 1-2 mol\% Sn doped ZnO nanoparticles afforded over $90 \%$ of BHETA. Structure and purity of BHETA, depolymerised product characterized by FT-IR, ${ }^{1} \mathrm{HNMR},{ }^{13} \mathrm{C} N \mathrm{NR}$, and MS.

\section{Introduction}

Zinc oxide $(\mathrm{ZnO})$ is a unique material when compared to other metal oxides,because of its cost-effectiveness and tunable catalytic properties. The catalytic efficiency of $\mathrm{ZnO}$ inherited from the tailor made electronic properties and nanostructure. Advancements in synthetic procedure as developed widen $\mathrm{ZnO}$ in various applications [1-4]. The crystal structure of ZnO comprises zinc blende and wurtzite, a hexagonal structure which can doped with metals and non-metals [1]. Zinc oxide is a binary semiconducting material having pyroelectric and piezoelectric properties (60 $\mathrm{meV}), \mathrm{ZnO}$ has a high redox potential, superior physical and chemical stability, and non-toxicity [2]. The major advantage of $\mathrm{ZnO}$ nanoparticles over others is their large surface area combined with reduced size, which makes it applicable in many areas like biological study including (antimicrobial activity), the photocatalytic and semiconducting properties which make it admit the use of $\mathrm{ZnO}$ nanoparticles as a potential candidate for many catalytic transformations $[4,5]$. The catalytic activity of $\mathrm{ZnO}$ nanoparticles can be tuned by doping process and it is seems to be one of the economical solutions [6]. Doping is mainly of two types: one is cationic and the other is of anionic doping. Introducing cationic impurities into the $\mathrm{ZnO}$ structure known as cationic doping, most prominently transition metals used as cationic dopants, eg: $\mathrm{Sn}, \mathrm{Al}, \mathrm{Ga}, \mathrm{In}, \mathrm{Cd}, \mathrm{Cu}, \mathrm{Mn}, \mathrm{Ni}$. The doping of an anion into $\mathrm{ZnO}$ called anionic doping, eg; As, $\mathrm{N}$, and $\mathrm{S}$ are anionic dopants [1, 3].

In the current investigation, we aim to depolymerise post-consumer PET wastes completely into pure terephathalamide monomer using aminolysis. Forasmuch PET is one of the most important engineering polymers and considered being an excellent material for many applications, including clothing applications. It has excellent tensile and impact strength, chemical resistance, clarity, processability, colorability, and reasonable thermal stability [7]. PET is an aromatic polyester mainly utilised for packaging and textile industries and the post-consumer waste recycling of PET using chemical methods rather than physical and land filling method is a most economical method to achieve circular economy in polyester industries because of its widespread commercial applications $[8,9]$. The total consumption of plastics in India is about 4 million tons and the waste generated is about 2 million tons. Plastics contributing to about $20 \%$ of solid municipal waste in India. The overall world consumption of PET currently amounts to about 13 million tons, of which 9.5 million tons processed by the textiles industry, 2 million tons used in the manufacture of audio and videotapes, and 1.5 million tons used in the manufacture of various types of packaging mainly bottles and jars [10]. PET is a noxious material because of its high resistance to atmospheric and biological agents. Ecological and 
economic considerations advocate the introduction of wide-scale PET recycling, similar to the recycling of traditional materials such as glass, paper, or metals [11].

\section{Aminolytic depolymerization of PET waste}

PET recycling is one of the most successful and best examples of polymer recycling. There are many processes by which post-consumer PET waste recycled, but the sustainable method is the chemical recycling process because it leads to the formation of monomers from which the polymer made $[8,12]$. In contrary, the conventional disposal methods such as landfilling become sereve threat terrastial and aquatic lives due to microplastics pollution [13, 14]. Chemical recycling process of PET divided: (i) glycolysis, (ii) methanolysis, (iii) hydrolysis, (iv) aminolysis, and (v) ammonolysis. Among the chemical recycling techniques, glycolysis and aminolysis depolymerization of the PET wastes produced bis (2-hydroxy ethyl) terephthalate (BHET) and bis (2-hydroxymethyl) terephthalamide catalysed by Lewis acidic heterogeneous catalysts $[15,16]$. Aminolysis is any chemical reaction in which post-consumer PET waste completely depolymerized into monomers by reacting with a molecule of an amine. Aminolysis is a method for PET chemolysis which has been relatively lesser explored when compared to other processes. There are only a few literature references regarding the chemolysis of the waste PET using different amines such as ethanolamine, triethanol amine, allylamine, and polyamines [17-19]. The catalytic systems reported for glycolysis and aminolysis recycling of PET wastes summarised in Table 1. 
Table 1

Glycolysis and aminolysis recycling of PET

\begin{tabular}{|c|c|c|c|c|c|c|}
\hline S.No & Process & Reactants & Catalysts Used & Yields & Products & References \\
\hline 1 & Aminolysis & Diethanolamine & $\begin{array}{l}\text { DES (Choline chloride. } \\
\mathrm{x} \mathrm{ZnCl}_{2} \text { or Choline } \\
\text { chloride. } 2 \text { Urea) }\end{array}$ & $95 \%$ & $\begin{array}{l}\text { (2-hydroxyethyl)- } \\
\text { terephthalamide } \\
\text { (THETA) }\end{array}$ & [20] \\
\hline 2 & Methanolysis & Methanol & $\begin{array}{l}\text { Potassium carbonate } \\
\left(\mathrm{K}_{2} \mathrm{CO}_{3}\right)\end{array}$ & $93 \%$ & $\begin{array}{l}\text { dimethyl } \\
\text { terephthalate } \\
\text { (DMT). }\end{array}$ & [21] \\
\hline 3 & Glycolysis & ethylene glycol & $\begin{array}{l}\mathrm{Fe}_{3} \mathrm{O}_{4} @ \mathrm{SiO}_{2} @(\mathrm{mim}) \\
{\left[\mathrm{FeCl}_{4}\right]}\end{array}$ & $\% 84$ & $\begin{array}{l}\text { bis(2-hydroxy } \\
\text { ethyl)terephthalate } \\
\text { (BHET }\end{array}$ & [22] \\
\hline 4 & Glycolysis & ethylene glycol & $\begin{array}{l}\mathrm{Al}^{3+}, \mathrm{Fe}^{3+} \text { and } \mathrm{Zn}^{2+} \\
\text { exchanged Bentonite } \\
\text { catalysts }\end{array}$ & $90 \%$ & $\begin{array}{l}\text { bis(2-hydroxy } \\
\text { ethyl)terephthalate } \\
\text { (BHET) }\end{array}$ & [15] \\
\hline 5 & Aminolysis & $\begin{array}{l}\text { 3-amino-1- } \\
\text { propanol }\end{array}$ & $\begin{array}{l}\text { sodium acetate as } \\
\text { catalyst. }\end{array}$ & $84 \%$ & $\begin{array}{l}\text { bis-(3-hydroxy } \\
\text { propyl) } \\
\text { terephthalamide } \\
\text { (BHPTA) }\end{array}$ & [23] \\
\hline 6 & Glycolysis & Ethylene glycol & $\begin{array}{l}\text { 1,3- } \\
\text { Dimethylurea/Zn(OAc) } 2 \\
\text { Deep Eutectic Solvent }\end{array}$ & $82 \%$ & $\begin{array}{l}\text { bis(hydroxyalkyl) } \\
\text { terephthalate } \\
\text { (BHET) }\end{array}$ & [24] \\
\hline 7 & Ammonolysis & ammonia $\left(\mathrm{NH}_{3}\right)$ & Zinc acetate & $87 \%$ & $\begin{array}{l}\text { terephthaldiamide } \\
\text { (TPA) }\end{array}$ & [25] \\
\hline 8 & Hydrolysis & $\mathrm{H}_{2} \mathrm{O}$ & ZSM-5 based zeolites & $92 \%$ & $\begin{array}{l}\text { terephthalic acid } \\
\text { (TPA). }\end{array}$ & [26] \\
\hline 9 & Alcoholysis & $\mathrm{MeOH}$ & ZnO nanoparticles & $95 \%$ & $\begin{array}{l}\text { dimethyl } \\
\text { terephthalate } \\
\text { (DMT) }\end{array}$ & [27] \\
\hline 10 & Aminolysis & $\begin{array}{l}\text { hydrazine } \\
\text { monohydrate } \\
\text { (HMH) }\end{array}$ & sodium carbonate & $84 \%$ & $\begin{array}{l}\text { hydrazine } \\
\text { monohydrate } \\
(\mathrm{HMH})\end{array}$ & [28] \\
\hline 11 & Glycolysis & $\begin{array}{l}\text { Ethylene Glycol } \\
\text { (EG) }\end{array}$ & Nano ZnO catalyst & $90 \%$ & $\begin{array}{l}\text { bis (2- hydroxy } \\
\text { ethyl) } \\
\text { terephthalate } \\
\text { (BHET) }\end{array}$ & [29] \\
\hline
\end{tabular}

In the current study, the chemical recycling of post-consumer PET polymer wastes, especially wastewater bottles, using the aminolysis process. The aminolysis of the PET wastes using the Sn(II) substituted ZnO nanoparticles as catalyst. $\mathrm{Sn} / \mathrm{ZnO}$ catalysts showed enhancement in photocatalytic, electron transport behaviourand sensitive to organic molecule containing carbonyl group such as formaldehyde [30-33]. The doping of Sn on ZnO reduced the band gap and promote catalytic behaviour. Sn(II) substituted $\mathrm{ZnO}$ nanoparticles prepared by the sol-gel method at different $\mathrm{Sn}^{2+}$ to $\mathrm{Zn}^{2+}$ molar ratio and characteriz using FTIR, XRD, UV-Vis and SEM-EDS analysis. Depolymerization of PET wastes using aminolysis under various parameters such as temperature, PET-to-catalyst ratio, and PET-to-aminolytic reagents. The final product of the aminolysis process characterised using ${ }^{1} \mathrm{H},{ }^{13} \mathrm{C}$ NMR and MS.

\section{Materials And Methods}


Common chemicals such as zinc nitrate hexahydrate, tin(II) chloride dihydrate, diethylamine, sodium hydroxide, ethanolamine, acetone, ethyl acetate, and n-hexane, all chemicals purchased from SRL and Loba Pvt, Ltd India and used without further purification. Post-consumer PET waste obtained from wastewater bottles collected, cleaned PET bottles dried at $80^{\circ} \mathrm{C}$ for 6 hours and cut into smaller pieces. All glassware and Quickfits we employed in the experimental work made up of corning/borosil glass. These glasswares washed thoroughly and dried in a hot air oven before use.

\subsection{Synthesis of catalyst}

Tin-doped ZnO nanoparticles were synthesized by the sol-gel method. Zinc nitrate hexahydrate and tin(II) chloride dihydrate dissolved in $50 \mathrm{ml}$ of distilled water. $\mathrm{NaOH}$ used as the base and diethylamine was used as a stabilizer to get the desired $\mathrm{pH}$ value of 11 . The mixture kept under constant magnetic stirring for $5 \mathrm{~h}$. After stirring the solution with reflux at $70-75^{\circ} \mathrm{C}$ for 4 hours and filtered by vacuum. During the filtration, the solution washed with distilled water many times to avoid impurities. After filtration, the filtered sample heated to $80^{\circ} \mathrm{C}$ in the oven for 24 hours. The heated sample was ground and calcined at $500{ }^{0} \mathrm{C}$ for 1 hour. $\mathrm{ZnO}$ nanoparticles substituted with $\mathrm{Sn}^{2+}$ in different $\mathrm{Sn}^{2+}$ molar ratios of $0.0,0.05,0.1$ and 0.2 prepared by a sol-gel process [32].

\subsection{Catalytic activity}

The catalytic activity of $\mathrm{Sn}^{2+}$ - substituted $\mathrm{ZnO}$ nanoparticles studied toward aminolysis of poly (ethylene terephthalate) waste using ethanolamine as aminolytizing agent. $\mathrm{Sn}^{2+}$-substituted $\mathrm{ZnO}$ in different $\mathrm{Sn}^{2+}$ molar ratios $0.5 \%, 1.0 \%$ and $2.0 \%$ were prepared by the same procedure [20].

\section{Aminolysis of PET wastes using ethanolamine}

The aminolysis of PET wastes collected from post-consumer beverage bottles was depolymerized using ethanolamine as an aminolyting agent afforded bis(2-hydroxyethyl) terephthalamide (BHETA) as a depolymerized product (Scheme 1) $[32]$.

For depolymerization, the aminolysis of Post-consumer PET bottles was collected. After removing the cap and labels they were cleaned thoroughly with soap water followed by distilled water. $100 \mathrm{ml}$ round-bottom glass equipped with a condenser, thermometer and magnetic stirrer. PET flakes $(500 \mathrm{mg})$ were treated with $20 \mathrm{ml}$ of ethanolamine and heated to $150-160^{\circ} \mathrm{C}$ using magnetic stirring. After reaching the desired temperature, the reaction mixture stirred for 1 hour. The PET was dissolved in ethanolamine. And then $50 \mathrm{mg}$ of $\mathrm{Sn}^{2+}$ - substituted $\mathrm{ZnO}$ nanoparticles catalyst was added. The temperature of the reaction was maintained using a temperature controller. After $1 \mathrm{~h}, 1 \mathrm{ml}$ of the reaction mixture was diluted with acetone and the progress of the reaction was monitored using precoated aluminium TLC plates (E-Merck, UK, Silicagel G60 F254 indicator) and the spots identified using $356 \mathrm{~nm}$ UV detector. The reaction progress was monitored by the TLC method using 70:30 v/v mixtures of n-hexane and ethyl acetate solvents and spot of BHETA compared with refernce BHETA compound. The reaction mixture was stirred for $3 \mathrm{~h}$. At the end of the reaction, $50 \mathrm{ml}$ of distilled water was added in excess to the reaction mixture with vigorous agitation and followed by filtration to remove the catalyst. After removal of catalysts, the filtrate heated to $70^{\circ} \mathrm{C}$ for 15 min and kept in $15-20{ }^{\circ} \mathrm{C}$ for 12-16 hrs. BHETA obtained as white needle crystals, which filtred and dried at $70{ }^{\circ} \mathrm{C}$ for $2 \mathrm{~h}$ at vaccum. Finally, the yield of the reaction is calculated from the weight of the final product. Further, the final product subjected to FT-IR, ${ }^{1} \mathrm{H}$,

${ }^{13} \mathrm{C}$ NMR and MS to confirm the structure and purity of BHETA. Likewise, the same procedure used for Sn ${ }^{2+}$-substituted ZnO nanoparticles having $0.5 \%, 1.0 \%$ and $2.0 \%$ molar ratio of $\mathrm{Sn}$ (II) dopant.

\subsection{Characterization techniques used for catalysts}


2.3.1 X-ray diffraction (XRD): XRD is a very important experimental technique used to determine the crystal structure of solids, including lattice constant and geometry, identification of unknown materials, atomic spacing, the orientation of the single crystal, preferred orientation of polycrystal, defects, stresses, etc. XRD was performed using a wide-angle Xray diffractometer with a graphite monochromator and $\mathrm{Cu}$ Ka sources. The X-ray generator was operated at $40 \mathrm{kV}$ and $30 \mathrm{~mA}$. XRD analysis was performed on a PANalytical Empyrean powder diffractometer at a $2 \theta$ angle between 20 and $80^{\circ}$.

2.3.2 FT IR spectroscopy: FTIR analysis is an analytical technique used to identify functional groups of synthesised SZO catalysts and depolymerised products. The IR absorption of the SZO nanoparticles shows an absorption band for hydroxyl, carbonyl and alkyl groups. IR spectra of the SZO and BHETA recorded on FT-IR SHIMADZU, IRTRACER 100 on solid sample as $\mathrm{KBr}$ pellet.

2.3.3 UV-Vis spectroscopy: UV-vis spectroscopy used to characterize the optical absorption properties of Sn(II) doped ZnO. The effect of doping on the optical band gap and crystalline quality investigated using ultraviolet-visible (UV-vis). Light absorption properties were measured by UV Vis 3600 PLUS - SHIMADZU in the wavelength range of 200-800 nm.

2.3.4 SEM-EDS: The morphological changes, elemental mapping and elemental composition of pure and Sn(II) doped ZnO nanoaparticles were observed and determined using FE-SEM (Thermosceintific Apreo S) connected with energy dispersive X-ray spectroscopy (EDS).

2.3.5 NMR and MS: ${ }^{1} \mathrm{H}$ and ${ }^{13} \mathrm{C}$ NMR spectrum of BHETA was analysed using Bruker Avance III operating at $500 \mathrm{MHz}$ in $\mathrm{CDCl}_{3}$ solvent. The mass spectrum of BHETA was obtained using Shimadzu LCMS-2020.

\section{Results And Discussions}

3.1 Synthesis of Sn(II) substituted ZnO nanoparticles using the sol-gel method: The commercially available zinc nitrate hexahydrate, tin(II) chloride dihydrate, diethylamine, sodium hydroxide, and ethanolamine were purchased from Loba Chem Pvt Ltd, India. Sn(II) substituted ZnO nanoparticles were synthesized from a sol-gel method [30, 31]. Initially, $\mathrm{Zn}\left(\mathrm{NO}_{3}\right)_{2} \cdot 6 \mathrm{H}_{2} \mathrm{O}$ and $\mathrm{SnCl}_{2} \cdot 2 \mathrm{H}_{2} \mathrm{O}\left(1 \mathrm{~mol} \%\right.$ with respect to $\left.\mathrm{Zn}^{2+}\right)$ were dissolved in $50 \mathrm{ml}$ of distilled water, the mixture was kept under constant magnetic stirring for 15 minutes at room temperature. Then, diethylamine (30 ml) was added dropwise using a burette. Mean the time $\left(\mathrm{NH}_{4} \mathrm{HCO}_{3}\right)(2 \mathrm{M})$ was also added dropwise for mainiting $\mathrm{pH}$ at 11. After that, the solution was kept under constant magnetic stirring for 5 hours at room temperature. A milky white precipitate was observed. Then, the obtained residue (SZO) was filtered and cleaned many times with deionized water. The final product was kept in an oven at $80^{\circ} \mathrm{C}$ for 24 hours to dry the product and remove moisture. Finally, the product of $\mathrm{ZnO}$ substituted $\mathrm{ZnO}$ was heated in a static air furnace at $500^{\circ} \mathrm{C}$ for $1 \mathrm{~h}$. Sn(II) substituted $\mathrm{ZnO}$ in different $\mathrm{Sn}$ (II) molar ratios of $0.5 \%, 1.0 \%$ and $2.0 \%$ were prepared using the same procedure and the yield of Sn(II) doped ZnO NPS summarised in Figure 1.

3.2 XRD pattern of tin-doped zinc oxide nanoparticle catalysts: The XRD pattern of Sn(II) doped ZnO nanoparticles synthesized by the sol-gel method. The powder XRD patterns have been recorded from 20 to $80^{\circ}$ two theta angles. Figure 2 shows the XRD patterns of the tin-doped ZnO nanoparticles with molar ratios of $0.5,1.0$ and $2.0 \%$ of $\mathrm{Sn}$ (II).

The change in the crystalline pattern of the Sn(II) substituted ZnO compared with pure zinc oxide nanoparticles. The obtained diffraction patterns of the nanopowders suggest that ZnO showed sharp peaks confirm the good crystalline 
with a hexagonal wurtzite structure. The peak observed at $2 \theta=31.50,33.760,35.90,47.230,56.180,62.20$ and 67.60 corresponds to the lattice plane (100), (002), (101), (102), (110), (103) and (112), respectively, indicative of the hexagonal structure of wurtzite of $\mathrm{ZnO}[30,31]$.

The reflections (100), (002) and (101) are of high intensity, and other reflections (102), (110), (103) and (112) are of lower intensity. Since the (101) reflection is the highest in all samples, we can conclude that that the particles are oriented mostly in the [101] direction. It means that $\mathrm{Sn}^{2+}$ has been successfully doped. The substitution of different $\mathrm{Sn}^{2+}$ catalysts did not change the hexagonal crystal structure of the wurtzite phase.

Table 1

Yield, lattice parameter, crystallite size and lattice strain of ZnO and Sn-doped ZnO

\begin{tabular}{|c|c|c|c|c|c|c|c|}
\hline \multirow[t]{2}{*}{ Material } & \multicolumn{3}{|c|}{ Lattice parameters } & \multirow{2}{*}{$\begin{array}{l}\text { volume } \\
\left(\mathrm{nm}^{3}\right)\end{array}$} & \multirow{2}{*}{$\begin{array}{l}\text { Crystallite size (nm) } \\
\text { (Scherrer equation) }\end{array}$} & \multirow{2}{*}{$\begin{array}{l}\text { Crystallite size (nm) } \\
\text { (W-H equation) }\end{array}$} & \multirow{2}{*}{$\begin{array}{l}\text { Lattice strain } \\
€ \times 10^{-3}\end{array}$} \\
\hline & $\stackrel{a}{(\AA)}$ & $\begin{array}{l}c \\
(\AA)\end{array}$ & $c / a$ & & & & \\
\hline ZnO & 1.69 & 5.19 & 3.05 & 12.98 & 37.65 & 80.4 & 1.4 \\
\hline $\begin{array}{l}0.5 \mathrm{~mol} \% \\
\text { Sn-ZnO }\end{array}$ & 1.69 & 5.17 & 3.05 & 12.89 & 19.3 & 38.1 & 2.25 \\
\hline $\begin{array}{l}\text { 1.0mol\% } \\
\text { Sn-ZnO }\end{array}$ & 1.93 & 5.19 & 2.67 & 16.92 & 21.75 & 49.9 & 2.275 \\
\hline $\begin{array}{l}2.0 \mathrm{~mol} \% \\
\text { Sn-ZnO }\end{array}$ & 2.05 & 5.2 & 2.53 & 19.02 & 15.2 & 15.7 & 2.5 \\
\hline
\end{tabular}

The crystallite size was calculated by the Scherrer equation and the Williamson-Hall equation. The crystallite size determined from the three peaks (100), (002) and (101) and the average size is calculated. The crystallite size obtained from Scherrer equation is smaller than the size obtained from the Williamson-Hall equation is observed from Table 1. The crystallite size is decreased on increasing the doping amount of tin \% [31]. The crystallite size calculated using Scherrer and $\mathrm{W}-\mathrm{H}$ method coincide that doping of $\mathrm{Sn}$ (II) reduced the crystallite size with respect to the dopant concentration. Similar trend have reported by Siva et al (2020 [31]. In contrary, the lattice strain increased from 1.4 to 2.5 while increasing the dopant concentration due to incorporation of higher ionic radius of Sn(II) in ZnO framework.

\subsection{FT-IR spectra of pure and Sn-doped ZnO nanoparticles}

FT-IR transmittance spectra of pure and Sn(II) doped zinc oxide nanoparticles of different molar ratios shown in Figure 3 , respectively. The spectrum was recorded from 500 to $3500 \mathrm{~cm}^{-1}$. In the pure and different molar ratio of $0.5 \%, 1.0 \%$, and $2.0 \% \mathrm{Sn}^{2+}$, no significant change in vibrational stretching of $\mathrm{ZnO}$ observed in the SZO samples compared to the pure synthesized ZnO. For all the samples, major and broad peaks were found between $500 \mathrm{~cm}^{-1}$ and $800 \mathrm{~cm}^{-1}$ is assigned due to the stretching vibration of $\mathrm{Zn}-\mathrm{O}$. These vibrational frequencies change to $800 \mathrm{~cm}^{-1}$ with an increase in Sn doping. The signals were found in the region $1400 \mathrm{~cm}^{-1}-1700 \mathrm{~cm}^{-1}$ and may be due to $\mathrm{C}=\mathrm{C}$ and $\mathrm{C}=0$ vibrations. Other signals near between $2000 \mathrm{~cm}^{-1}$ and $2400 \mathrm{~cm}^{-1}$ were also observed. Finally, significant peaks were found between $3200 \mathrm{~cm}^{-1}$ and $3500 \mathrm{~cm}^{-1}$. These peaks were attributed to the $\mathrm{H}_{2} \mathrm{O}$ stretching vibration in the $\mathrm{ZnO}$ lattice [34].

\subsection{UV-vis absorbance spectra of pure and Sn-doped ZnO nanoparticles:}


UV absorption spectra are analyzed for all samples from $200 \mathrm{~nm}$ to $800 \mathrm{~nm}$. The optical properties of prepared Sndoped ZnO nanoparticles were examined by UV Vis spectroscopy (UV Vis 3600 PLUS - SHIMADZU). The UV-Visible spectra of the sample Sn (II) doped ZnO nanoparticles showed in Figure 4. Different molar ratios of 0.5\%, 1.0\%, and $2.0 \%$ of the $\mathrm{Sn}^{2+}$ doped $\mathrm{ZnO}$ samples exhibit a well-defined absorption peak that corresponds to the hexagonal wurtzite phase [30, 31].

The peaks of the the excitonic absorption was between 380 and $400 \mathrm{~nm}$, which are typical characteristic ZnO NPs peaks, thus, confirm their presence. The bandgap of Sn doped ZnO (molar ratio 1\%) is decrease compared to the other molar ratios are 0.5 and $2 \%$. The shifting in absorption peak to the higher wavelength results in decreasing the band gap for Sn- ZnO nanoparticles from 3.23 to $3.12 \mathrm{eV}$. The incorporation of Sn(II) enhanced photocatalytic activity. The optical direct band gap calculated from the formula $\mathrm{Eg}=\mathrm{hc} / \mathrm{l}$ is $3.24 \mathrm{eV}$ [31].

\subsection{HR SEM-EDS:}

SEM-EDS study was carried out to examine the morphological changes, particle size, elemental composition of the pure and Sn doped ZnO NPs. SEM images, elemental mapping and EDS signals and their percentage composition of pristine and 1 mol\% Sn doped ZnO NPs are shown in Figure 5a-5f. For un-doped ZnO NPs, sharp signals were found for zinc and oxygen, which confirms the formation of ZnO NPs. For $1 \mathrm{~mol} \%$ Sn-doped sample along with Zn(II), 0 and Sn(II) signals observed in EDS.

Figures $5 \mathrm{a}$ and $5 \mathrm{~b}$ showed HR-SEM images of pure $\mathrm{ZnO}$ and $1 \mathrm{~mol} \% \mathrm{Sn}$ doped $\mathrm{ZnO}$ magnified at $1 \mu \mathrm{m}$ and $800 \mathrm{~nm}$. SEM images showed that nanoparticles are well dispersed. The ZnO nanoparticles formed are found to be $30-40 \mathrm{~nm}$ in size. The ZnO NPs formed in clusters with well-distinguished nanoparticles. The crystallite size calculated using the Scherrer equation and the William - Hall method obtained from the XRD data also confirmed the formation of 30 - 40 $\mathrm{nm} \mathrm{ZnO}$ nanoparticles. Further, Figure 5b presented $1 \mathrm{~mol} \% \mathrm{Sn}$ doped ZnO nanoparticles magnified at $1 \mu \mathrm{m}$, the size of $\mathrm{Sn} / \mathrm{ZnO}$ nanoparticles found to be in the range of $30-40 \mathrm{~nm}$. The XRD pattern also supported the crystallite size observed to be in the range of 30 to $40 \mathrm{~nm}$, as shown in in Table 1. Elemental mapping and the EDS spectrum of pure $\mathrm{ZnO}$ and $1 \mathrm{~mol} \% \mathrm{Sn}$ doped $\mathrm{ZnO}$ are shown in Figures $5 \mathrm{c}-5 \mathrm{f}$ (percentage composition of pure $\mathrm{ZnO}$ and $1 \mathrm{~mol} \% \mathrm{Sn}$ doped ZnO given in supplementary information, Table S1 and Table S2). The ZnO doped with $1 \mathrm{~mol} \% \mathrm{Sn}$ appeared to be well defined nanoparticles cluster at $1 \mu \mathrm{m}$ magnification. Elemental mapping of $1 \mathrm{~mol} \% \mathrm{Sn} / \mathrm{ZnO}$ showed the presence of both $\mathrm{Zn}$ as well as Sn atoms (Figure $6 \mathrm{c}$ and $6 \mathrm{~d}$ ) [31]. In addition, the EDS spectrum for 1 mole Sn doped $\mathrm{ZnO}$ showed the presence of $\mathrm{Zn}$ as well as $\mathrm{Sn}$ and elemental composition showed as shown in Figure $5 \mathrm{e}$ and $5 \mathrm{f}$ determined $\mathrm{Zn}^{2+}$ at $80.13 \%$ and $\mathrm{Sn}^{2+}$ and at $0.74 \%$, which is very close to $1 \mathrm{~mol} \% \mathrm{Sn}$ (II) doping on $\mathrm{ZnO}[35,36]$.

\section{Depolymerization of PET polymer using ethanolamine:}

The deoplymerisation of PET wastes using ethanolamine as aminolyting agent which yield BHETA as a single product $[37,38]$. The aminolysis reaction activated by Lewis acidic nature of $\mathrm{ZnO}$, in which carbonyl group of terephthalic ester carbonyl group attracted by ZnO [24]. Further, the incorporation of Sn(II) enhances its catalytic acitivity to give BHETA as a single product. Figure $6 \mathrm{a}-\mathbf{d}$ showed the aminolysis of PET wastes using ethanolamine (EA) carried out to study the effect of Sn(II) loadings (Fig. 6a), PET-to-EA ratio (Fig. 6b), catalyst-to-PET ratio (Fig. 6c), and efficiency of catalyst with respect to reaction cycle (Fig. 6d).

Figure 6a showed the effect of $\mathrm{Sn}^{2+}$ loading on the yield of bis (hydroxy ethyl) terephthalimide. The increasing doping of $\mathrm{Sn}^{2+}$ has positive influence on the yield of (BHETA). However, ZnO NPs showed yielded $83 \%$ of BHETA. 1 and 2 mol\% of doping of $\mathrm{Sn}^{2+}$ on the $\mathrm{ZnO}$ enhanced BHETA yield upto 95\%. The increase in BHETA yield could speculated due to the addition of $2 \mathrm{~mol} \% \mathrm{Sn}^{2+}$ reduced the bandgap from 3.25 to $3.17 \mathrm{eV}$, which increased the catalytic efficiency 
of the ZnO. The optical bandgap calculated from the Tauc plot (Figure 3) indicates the decrease in the band gap when increasing the amount of $\mathrm{Sn}^{2+}$ doping reported that increasing the amount of $\mathrm{Sn}^{2+}$ doping from 3 to $5 \%$ as prepared using the coprecipitation method increased the photocatalytic efficiency of ZnO. According to Fig. 6a, the doping of 1 $\mathrm{mol} \%$ and $2 \mathrm{~mol} \% \mathrm{Sn}$ loaded ZnO showed BHETA yield more than 95\% the single product. The BHETA is hot-water soluble, which have been isolated and crystallised as needle shaped pale yellow-coloured crystals without any further purification. As observed in Fig. 6a, the pristine ZnO showed almost 85\% BHETA without Sn doping. The analysis of BHETA showed the formation of single depolymerised product using the eluent $40: 60 \%$ of EA:Hex. In order to confirm the structure, FT-IR, ${ }^{1} \mathrm{H}$ NMR, ${ }^{13} \mathrm{C}$ NMR and MS analysis have been carried out. Both ${ }^{1} \mathrm{H}$ and ${ }^{13} \mathrm{C}$ NMR spectra showed pure form of BHETA.

Figure $6 \mathrm{~b}$ showed the effect of PET to EA ratio has been studied at various weight \% of PET:EA ratios. In this study, the amount of PET was kept constant at $1 \mathrm{~g}$, with respect to the volume of ethanolamine that varied from $1 \mathrm{ml}, 5 \mathrm{ml}, 10 \mathrm{ml}$, $15 \mathrm{ml}, 20 \mathrm{ml}$ and $25 \mathrm{ml}$ to achieve a ratio of 1:1, 1:5, 1:10,1:15, 1:20 and 1:25 of the PET: EA ratio. The study revealed that the the 1:1, 1: 5 and 1:10 ratio provided 60 to 70\% of BHETA. Whereas, 1:15-1:25 ratio afforded more than $80 \%$ of BHETA in particular, 1:20 ratio of PET:EA delivered $94 \%$ yield, while is almost comparable with yield obtained for 1:25 ratio. The dissolution of PET in lower ratio of EA is a major issue for the progress of the reaction (Gopal Jeya et al 2020, APM). Whereas, the 1:20 ratio could be more optimum for the smooth running of the reaction.

Figure $6 \mathrm{c}$ summarises the effect of the catalyst-to-PET ratio, which is crucial for the effective aminolysis of PET wastes. In this study, the amount of catalyst ( $1 \mathrm{~mol} \% \mathrm{Sn}$ doped $\mathrm{ZnO}$ ) has been fixed at $50 \mathrm{mg}$ throughout the study with respect to catalyst weight, the amount of PET wastes has been varied from $100 \mathrm{mg}$ to $500 \mathrm{mg}$ to achieve 1:2, 1:5, $1: 10,1: 15$, and $1: 20$ ratio. The study clearly indicated that the increasing amount of catalyst, that is, the catalyst-toPET ratio at 1:2, 1:5, 1:20, afforded the yield of BHETA above $90 \%$. However, the ratio at 1:15 almost gives an $85 \%$ yield of BHETA. The study revealed that the ratio of catalyst: 1: 5 to 1: 5 to PET could be optimal to achieve more than $85 \%$ of the aminolysed product, BHETA in pure and single product.

Figure $6 \mathrm{~d}$ displayed the recycling ability of $1 \mathrm{~mol} \%$ Sn-doped ZnO NPs towards aminolysis of PET. About $1 \mathrm{~g}$ of PET wastes dissolved in $20 \mathrm{ml}$ and stirred at $155-160{ }^{\circ} \mathrm{C}$ in the presence of $100 \mathrm{mg}$ of $1 \mathrm{~mol} \% \mathrm{Sn}$ doped ZnO. The study showed the catalyst could be reusable upto 7 cycles without losing its activity.

\section{Spectral characterisaion of BHETA}

The complete depolymerisation of PET wastes generate BHETA as a single product. However, there could be possibility of forming dimer and oligomeric products due to incomplete depolymerisation. Thus, spectral characterisation such as

${ }^{1} \mathrm{H}$ and ${ }^{13} \mathrm{C}$ NMR, and MS and FT-IR analysis have been carried out. The structural characterisation of depolymerised product, BHETA have been carried out to confirm the purity and structural confirmation. ${ }^{1} \mathrm{H}$ and ${ }^{13} \mathrm{C}$ NMR of BHETA is given Fig. 7a and 7b respectively (Full spectrum given in supplementrary information Figure S3 and S4), and chemical structure of Fig. 7e. The ESI-MS and FT-IR spectrum of BHETA given in Fig. 7c and 7d respectively. The ${ }^{1} \mathrm{H}$ NMR spectrum of BHETA showed two $\mathrm{NH}$ protons attached with amide carbonyl ( $\mathrm{C} 7$ and $\mathrm{C} 8)(-\mathrm{C}=0)$ and ethylene carbons ( $\mathrm{C} 9$ and $\mathrm{C} 10)\left(-\mathrm{CH}_{2}\right)$ appeared as triplet at $8.35-8.55$ with $\mathrm{J}$ value of $5.5 \mathrm{~Hz}$. The presence of $\mathrm{NH}$ protons confirms the depolymerisation and formation of BHETA. The number, position and multiplicity of aromatic protons give valid information on monomer, dimer and oligomeric nature of the depolymerised products. The skeleton of BHETA molecule is symmetrical, which confirmed from signal of aromatic protons attached to C1, C2, C4 and C5 appearing as singlet at $7.92 \mathrm{ppm}$ that shows not only BHETA is the pure and single product but also indicates complete depolymerisation of PET wastes. In addition, two $-\mathrm{OH}$ protons attached to methylene carbons $(\mathrm{C} 11$ and $\mathrm{C} 12)\left(-\mathrm{CH}_{2}\right)$ appeared as triplet at $4.74-4.76 \mathrm{ppm}$ with $5.5 \mathrm{~Hz}$. The protons of methylene group (C11 and C12) attached to $-\mathrm{OH}$ 
appeared as a quartet between 3.51 and $3.54 \mathrm{ppm}$ with $\mathrm{J}$ value of $6 \mathrm{~Hz}$. Another, methylene protons (C9 and C10) attached to amide - $\mathrm{NH}$ group gives quartet at 3.33-3.37 ppm with $\mathrm{J}$ value of $6 \mathrm{~Hz}$. The presence of eight aliphatic protons attached to two ethylene group $\left(-\mathrm{CH}_{2}-\mathrm{CH}_{2}-\right)$ confirms the attachment of two 2-hydroxy ethyl group to terephthaloylamido group (-NH-CO- $\left.\mathrm{C}_{6} \mathrm{H}_{4}-\mathrm{CO}-\mathrm{NH}-\right)$ of BHETA. Fig. $7 \mathrm{~b}$ is ${ }^{13} \mathrm{CNMR}$ spectrum of BHETA. The presence of two amide carbonyl ( $\mathrm{C} 7$ and $\mathrm{C} 8)(\mathrm{NH}-\mathrm{C}=0)$ appeared as single peak at $166.1 \mathrm{ppm}$ indicates that $\mathrm{BHETA}$ is formed as a single product in pure form from the complete depolymerization of PET wastes. The two aromatic carbons (C3 and C6) attached to amide carbonyl appeared at $137.1 \mathrm{ppm}$ and all other four carbons (C1, C2, C4 and C5) appeared as a triplet at $127.63-127.53 \mathrm{ppm}$. The methylene carbon (C11 and C12) attached to the hydroxyl group appeared as a single peak at $60.19 \mathrm{ppm}$. Whereas methylene carbons (C9 and C10) attached to NH-group at amide appeared at 40.7

ppm. Both ${ }^{1} \mathrm{H}$ and ${ }^{13} \mathrm{C}$ NMR confirmed the formation of BHETA as a single pure product. The product is isolated in pure form without the need for purification.

The mass spectrum of aminolysed product, bis (hydroxy ethyl) terephthalamide is given Fig. 7c (Full spectrum given in supplementary information, Figure S5). The molecular formula of BHETA is $\mathrm{C}_{12} \mathrm{H}_{16} \mathrm{~N}_{2} \mathrm{O}_{4}$ with molecular weight is $252.27 \mathrm{~g} / \mathrm{mol}$. The spectrum recorded using the electron spray ionisation method revealed the molecular ion peak at $253.15(\mathrm{M}+\mathrm{H})$ in the protonated form. Another peak at m/z 275.10 indicates the formation of $\mathrm{Na}+$ form of BHETA due to electron spray ionisation.

Furthermore, the FT-IR spectrum (Fig. 7d) of BHETA has been carried out as a $\mathrm{KBr}$ disc, and vibrational frequencies have been recorded from 400 to $4000 \mathrm{~cm}^{-1}$ (Full spectrum given in supplementery information, Figure S6). In 3250 $3400 \mathrm{~cm}^{-1}$ two sharp peaks observed due to the presence of $-\mathrm{NH}$ and $-\mathrm{OH}$ groups connected methylene carbon $\mathrm{C} 9$ and C10, and C11 and C12 in BHETA, respectively. The intermolecular $\mathrm{H}$-bonding ascertained from the broadness of the peaks. The aromatic $-\mathrm{CH}$ - stretching vibration observed at $2830-2860 \mathrm{~cm}^{-1}$ and aliphatic $\mathrm{CH}_{2}$ stretching vibration frequencies observed at $2920-2960 \mathrm{~cm}^{-1}$. The amide carbonyl (C7 and C8) (-NH-C=0) stretching vibration is observed at $1635 \mathrm{~cm}^{-1}$. The aromatic (C1-C6) $-\mathrm{C}=\mathrm{C}$ - stretching vibration observed in $1550 \mathrm{~cm}^{-1}$. In addition, $-\mathrm{OH}$ bending shown at $1180 \mathrm{~cm}^{-1}$ and aliphatic $-\mathrm{CH}$ skeletal vibration observed at $1090 \mathrm{~cm}^{-1}$. The presence of an aromatic and aliphatic $-\mathrm{OH}$ and $-\mathrm{NH}$ stretching vibration as well as amide carbonyl vibration confirmed the formation of BHETA.

\section{Conclusion}

In conclusion, compared with ZnO, Sn-doped ZnO showed excellent aminolysis yield of BHETA. The Sn-doped ZnO was synthesised by the Sol-gel method and was successfully characterised by XRD, UV-Vis, FT-IR, and SEM-EDX techniques. Diffraction patterns of the nanopowders suggest that ZnO has sharp peaks, which confirm the good crystalline structure with a hexagonal wurtzite structure. FT-IR spectroscopy shows the pure and different molar ratio of $0.5 \%, 0.1 \%$, and $0.2 \% \mathrm{Sn}^{2+}$ no significant change was observed in these samples as compared to the pure synthesized $\mathrm{ZnO}$. The reduction in bandgap of $\mathrm{ZnO}$ is observed upon doping with $\mathrm{Sn}$. In addition, as observed from XRD, doping resulted in an increase in the crystallite size of the nanoparticles. The SEM analysis of Sn doped ZnO NPs showed 30 - $40 \mathrm{~nm}$ size of the ZnO NPs comparable with the crystallite size calculated from powder XRD. The aminolysis of PET wastes has been successfully accomplished using Sn-doped ZnO nanoparticles. The depolymerization of PET polymer waste has been successfully achieved using a pure and different molar ratio of 0.5 , 0.1 and $0.2 \mathrm{Sn}$-doped $\mathrm{ZnO}$ nanoparticle catalyst aminolysis reaction at $155-160^{\circ} \mathrm{C} .1 \mathrm{~mol} \% \mathrm{Sn}$-doped $\mathrm{ZnO}$ yielded $95 \%$ of BHETA at $155-160^{\circ} \mathrm{C}$. The product is isolated in pure form without requiring further purification. Hence, from out investigation, we proposed Sn doped ZnO nanoparticles could be effective catalyst for aminolytic depolymerisation of PET wastes. We also observed is reusable up to 7 cycles without a major loss in the BHETA yield. The study provide that the use of $\mathrm{Sn}$ doped $\mathrm{ZnO}$ could be economical reusable catalyst for aminolysis of PET 
wastes. Currently, we are investigating ZnO doped with Ag, In and Cd towards catalytic depolymerisation various kinds of PET wastes including dyed polyester fabrics.

\section{Declarations}

\section{Acknowledgement}

The financial support received from the University Grants Commission (UGC) in the form of a minor research project [File No. F: MRP-6393/16 (SERO/UGC)] is gratefully acknowledged by Dr.V.Sivamurugan. All the authors are very thankful to Centralized Sophisticated Instrument Facilities (CSIF), Interdisciplinary Institute of Indian System of Medicine (IIISM), SRM Institute of Science and Technology, Katankulathur - 603203 and SCIF:SRM Central Instrumentation Facility, NANOTECHNOLOGY RESEARCH CENTRE for providing characterisation facilities.

\section{Conflict of Interest}

The authors have declared that they have no conflict of interest.

\section{Samples availability}

The sample of catalysts and BHETA available from the corresponding author.

\section{References}

1. Vinitha V, Preeyanghaa M, Vinesh V, Dhanalakshmi R, Neppolian B, Sivamurugan V (2021) Two is better than one: catalytic, sensing and optical applications of doped zinc oxide nanostructures. Emergent Mater 4:1093-1124 . https://doi.org/10.1007/s42247-021-00262-x

2. Singh P, Kumar R, Singh RK (2019) Progress on Transition Metal-Doped ZnO Nanoparticles and Its Application. Ind Eng Chem Res 58:17130-17163. https://doi.org/10.1021/acs.iecr.9b01561

3. Kumari V, Mittal A, Jindal J, Yadav S, Kumar N (2019) S-, N- and C-doped ZnO as semiconductor photocatalysts: A review. Front Mater Sci 13:. https://doi.org/10.1007/s11706-019-0453-4

4. Bharat TC, Shubham, Mondal S, Gupta HS, Singh PK, Das AK (2019) Synthesis of doped zinc oxide nanoparticles: A review. Mater Today Proc 11:767-775. https://doi.org/10.1016/j.matpr.2019.03.041

5. Borysiewicz MA (2019) ZnO as a functional material, a review. Crystals 9:. https://doi.org/10.3390/cryst9100505

6. Carofiglio M, Barui S, Cauda V, Laurenti M (2020) Doped zinc oxide nanoparticles: Synthesis, characterization and potential use in nanomedicine. Appl Sci 10: . https://doi.org/10.3390/app10155194

7. Rajabinejad H, Khajavi R, Rashidi M, Yazdanshenas ME (2009) Recycling of Used Bottle Grade Poly Ethyleneterephthalate to Nanofibers by Melt-electrospinning Method, International Journal of Environmental Research 3:663-67. DOI: 10.22059/IJER.2010.82

8. Payne J, Jones MD (2021) The Chemical Recycling of Polyesters for a Circular Plastics Economy: Challenges and Emerging Opportunities. ChemSusChem 14:4041-4070. https://doi.org/10.1002/cssc.202100400

9. Repp L, Hekkert M, Kirchherr J (2021) Circular economy-induced global employment shifts in apparel value chains: Job reduction in apparel production activities, job growth in reuse and recycling activities. Resour Conserv Recycl 171:105621 . https://doi.org/10.1016/j.resconrec.2021.105621

10. Thomas P, Rumjit NP, Lai CW, Johan MRB, Saravanakumar MP (2020) Polymer-Recycling of Bulk Plastics. Encycl Renew Sustain Mater 432-454 . https://doi.org/10.1016/b978-0-12-803581-8.10765-9 
11. Reis JML, Carneiro EP (2012) Evaluation of PET waste aggregates in polymer mortars. Construction and Building Materials, 27:107-111. doi:10.1016/j.conbuildmat.2011.08.020

12. Pohjakallio M, Vuorinen T, Oasmaa A (2020) Chapter 13 - Chemical routes for recycling-dissolving, catalytic, and thermochemical technologies. In: Letcher TMBT-PW and R (ed). Academic Press, pp 359-384

13. Revel M, Châtel A, Mouneyrac C (2018) Micro(nano)plastics: A threat to human health? Curr Opin Environ Sci Heal 1:17-23. https://doi.org/10.1016/j.coesh.2017.10.003

14. Palacios-Mateo C, van der Meer Y, Seide G (2021) Analysis of the polyester clothing value chain to identify key intervention points for sustainability. Environ Sci Eur 33: . https://doi.org/10.1186/s12302-020-00447-x

15. Jeya G, Anbarasu M, Dhanalakshmi R, Vinitha V, Sivamurugan V. (2020). Depolymerization of Poly(ethylene terephthalate) Wastes through Glycolysis using Lewis Acidic Bentonite Catalysts. Asian Journal of Chemistry. 32:187-191. doi:10.14233/ajchem.2020.22387.

16. Jeya G, Ilbeygi H, Radhakrishnan D, Sivamurugan V. (2017). Glycolysis of Post-Consumer Poly(ethylene terephthalate) Wastes Using Al, Fe and Zn Exchanged Kaolin Catalysts with Lewis Acidity. Advanced Porous Materials. 5:128-136. doi:10.1166/apm.2017.1141.

17. Jeya G, Rajalakshmi S, Gayathri KV, Priya P, Sakthivel P, Sivamurugan V. (2022) A Bird's Eye View on Sustainable Management Solutions for Non-degradable Plastic Wastes. In: Vasanthy M., Sivasankar V., Sunitha T.G. (eds) Organic Pollutants. Emerging Contaminants and Associated Treatment Technologies. Springer, Cham. https://doi.org/10.1007/978-3-030-72441-2_20

18. Jeya G, Dhanalakshmi R, Anbarasu M, Vinitha V, Sivamurugan V (2021) A short review on latest developments in catalytic depolymerization of Poly (ethylene terephathalate) wastes. J Indian Chem Soc 100291 . https://doi.org/https://doi.org/10.1016/j.jics.2021.100291

19. Shukla SR, Harad AM. (2006). Aminolysis of polyethylene terephthalate waste. Polymer Degradation and Stability, 91(8):1850-1854. doi:10.1016/j.polymdegradstab.2005.11.005

20. Musale RM, Shukla SR. (2016). Deep eutectic solvent as effective catalyst for aminolysis of polyethylene terephthalate (PET) waste. International Journal of Plastics Technology, 20:106-120. doi:10.1007/s12588-0169134-7

21. Pham DD, Cho J. (2021). Low-energy catalytic methanolysis of poly(ethylene terephthalate). Green Chemistry. doi:10.1039/d0gc03536j

22. Cano I, Martin C, Fernandes JA, Lodge RW, Dupont J, Casado-Carmona FA, de Pedro I. (2019). Paramagnetic lonic Liquid-Coated $\mathrm{SiO}_{2} @ \mathrm{Fe}_{3} \mathrm{O}_{4}$ Nanoparticles - the Next Generation of Magnetically Recoverable Nanocatalysts Applied in the Glycolysis of PET. Applied Catalysis B: Environmental, 260:

118110. https://doi.org/10.1016/j.apcatb.2019.118110

23. Kapadi PU, Shukla SR, Mhaske ST, More A, Mali MN. (2015) Development of corrosion resistant polyurethane coating from aminolytic depolymerization of PET bottle waste. Journal of Materials and Environmental Science $6: 119-128$

24. Liu B, Fu W, Lu X, Zhou Q, Zhang S. (2018). Lewis acid-base synergistic catalysis for PET degradation by 1,3dimethylurea/Zn(OAc) $)_{2}$ deep eutectic solvent. ACS Sustainable Chemistry \& Engineering. 7:3292-3300. doi:10.1021/acssuschemeng.8b05324

25. Bolanle A, Zainon Z, Hassan A (2019) Current Developments in Chemical Recycling of Post-Consumer Polyethylene Terephthalate Wastes for New Materials Production : A Review Current developments in chemical recycling of post-consumer polyethylene terephthalate wastes for new materials productio. J Clean Prod 225:1052-1064 . https://doi.org/10.1016/j.jclepro.2019.04.019

Page $12 / 20$ 
26. Jong Kang, M., Jin Yu, H., Jegal, J., Sung Kim, H., \& Gil Cha, H. (2020). Depolymerization of PET into Terephthalic Acid in Neutral Media Catalyzed by the ZSM-5 Acidic Catalyst. Chemical Engineering Journal, 125655. doi:10.1016/j.cej.2020.125655

27. Du JT, Sun Q, Zeng XF, Wang D, Wang JX, Chen JF. (2020). ZnO nanodispersion as pseudohomogeneous catalyst for alcoholysis of polyethylene terephthalate. Chemical Engineering Science, 220:115642. doi:10.1016/j.ces.2020.115642

28. George, N., \& Kurian, T. (2016). Sodium Carbonate Catalyzed Aminolytic Degradation of PET. Progress in Rubber Plastics and Recycling Technology, 32(3), 153-168. doi:10.1177/147776061603200304

29. Alzuhairi MAH, Khalil BI and Hadi RS (2017) Nano ZnO Catalyst for Chemical Recycling of Polyethylene terephthalate (PET). Engineering and Technology Journal 35: 831-837.

30. Harish S, Archana J, Navaneethan M, Silambarasan A, Nisha KD, Ponnusamy S, Muthamizhchelvan C, Ikeda H, Aswal DK, Hayakawa Y (2016) Enhanced visible light induced photocatalytic activity on the degradation of organic pollutants by SnO nanoparticle decorated hierarchical ZnO nanostructures. RSC Adv 6:89721-89731 . https://doi.org/10.1039/c6ra19824d

31. Siva N, Sakthi D, Ragupathy S, Arun V, Kannadasan N (2020) Synthesis, structural, optical and photocatalytic behavior of Sn doped ZnO nanoparticles. Mater Sci Eng B Solid-State Mater Adv Technol 253:114497. https://doi.org/10.1016/j.mseb.2020.114497

32. Shalan AE, El-Shazly AN, Rashad MM, Allam NK (2019) Tin-zinc-oxide nanocomposites (SZO) as promising electron transport layers for efficient and stable perovskite solar cells. Nanoscale Adv 1:26542662. https://doi.org/10.1039/c9na00182d

33. Ishak S, Johari S, Ramli MM (2020) Influence of Sn dopant on ZnO Thin Film for Formaldehyde Detection. J Phys Conf Ser 1535: . https://doi.org/10.1088/1742-6596/1535/1/012003

34. Kadam AN, Bhopate DP, Kondalkar V V., Majhi SM, Bathula CD, Tran AV, Lee SW (2018) Facile synthesis of Ag-ZnO core-shell nanostructures with enhanced photocatalytic activity. J Ind Eng Chem 61:78-86. https://doi.org/10.1016/j.jiec.2017.12.003

35. Ozugurlu E (2021) Cd-doped ZnO nanoparticles: An experimental and first-principles DFT studies. J Alloys Compd 861: . https://doi.org/10.1016/j.jallcom.2021.158620

36. Yarahmadi M, Maleki-Ghaleh H, Mehr ME, Dargahi Z, Rasouli F, Siadati MH (2021) Synthesis and characterization of Sr-doped ZnO nanoparticles for photocatalytic applications. J Alloys Compd 853:157000. https://doi.org/10.1016/j.jallcom.2020.157000

37. Achilias, D. \& Karayannidis, G. (2004). The chemical recycling of PET in the framework of sustainable development, Water, Air, \& Soil Pollution: Focus, Vol 4, No. 4-5, (October 2004), pp. 385-396, ISSN 1567-7230

38. Achilias DS, Tsintzou GP, Nikolaidis AK, Bikiaris DN, Karayannidis GP (2011) Aminolytic depolymerization of poly(ethylene terephthalate) waste in a microwave reactor. Polym Int 60:500-506 .

https://doi.org/10.1002/pi.2976

39. Allam, N., Shalan, A. E., El-hazly, A. N., \& Rashad, M. M. (2019). Tin-Zinc-Oxide Nanocomposites (SZO) as Promising Electron Transport Layers for Efficient and Stable Perovskite Solar Cells. Nanoscale Advances. doi:10.1039/c9na00182d

\section{Scheme}

Please see the Supplementary Files for the Scheme 1.

Page $13 / 20$ 
Figures

\section{Synthesis of $\mathrm{Sn}^{2+}$ - doped $\mathrm{ZnO}$ nanoparticles}

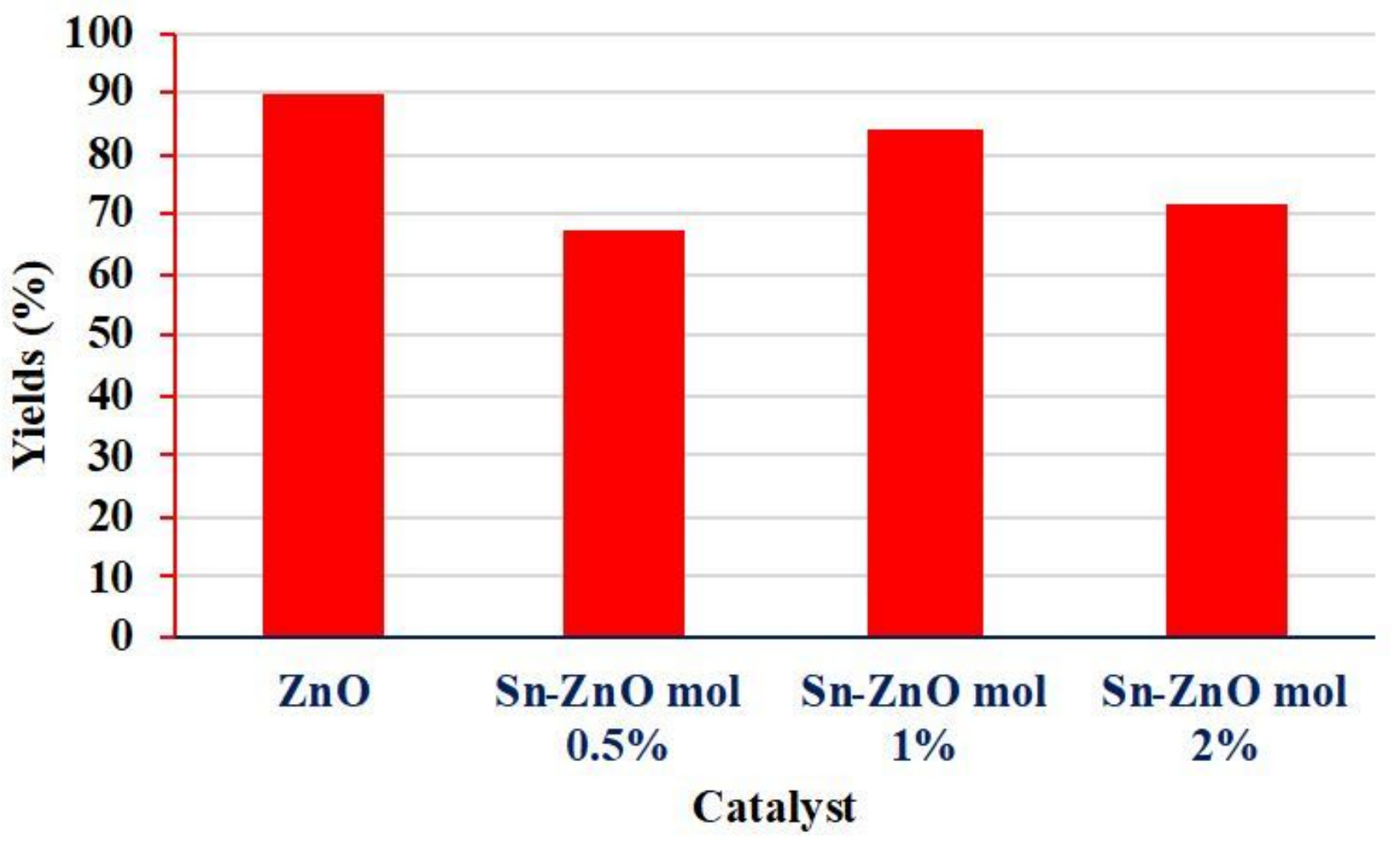

Figure 1

Yield of $\mathrm{Sn}^{2+}$ doped $\mathrm{ZnO}$ nanoparticles prepared by sol-gel method 


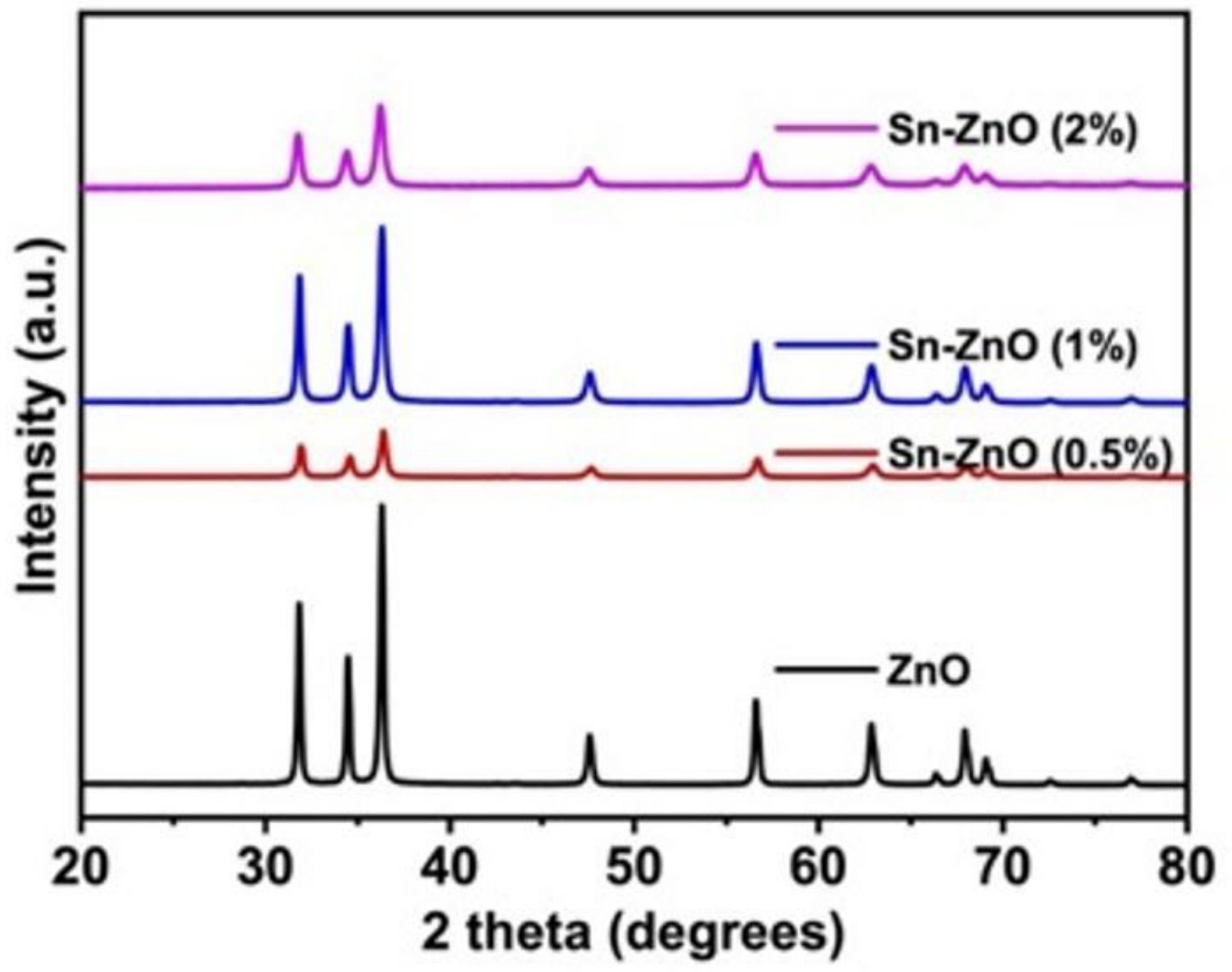

Figure 2

XRD patterns of pure and $\mathrm{Sn}$ doped $\mathrm{ZnO}$ nanoparticles 


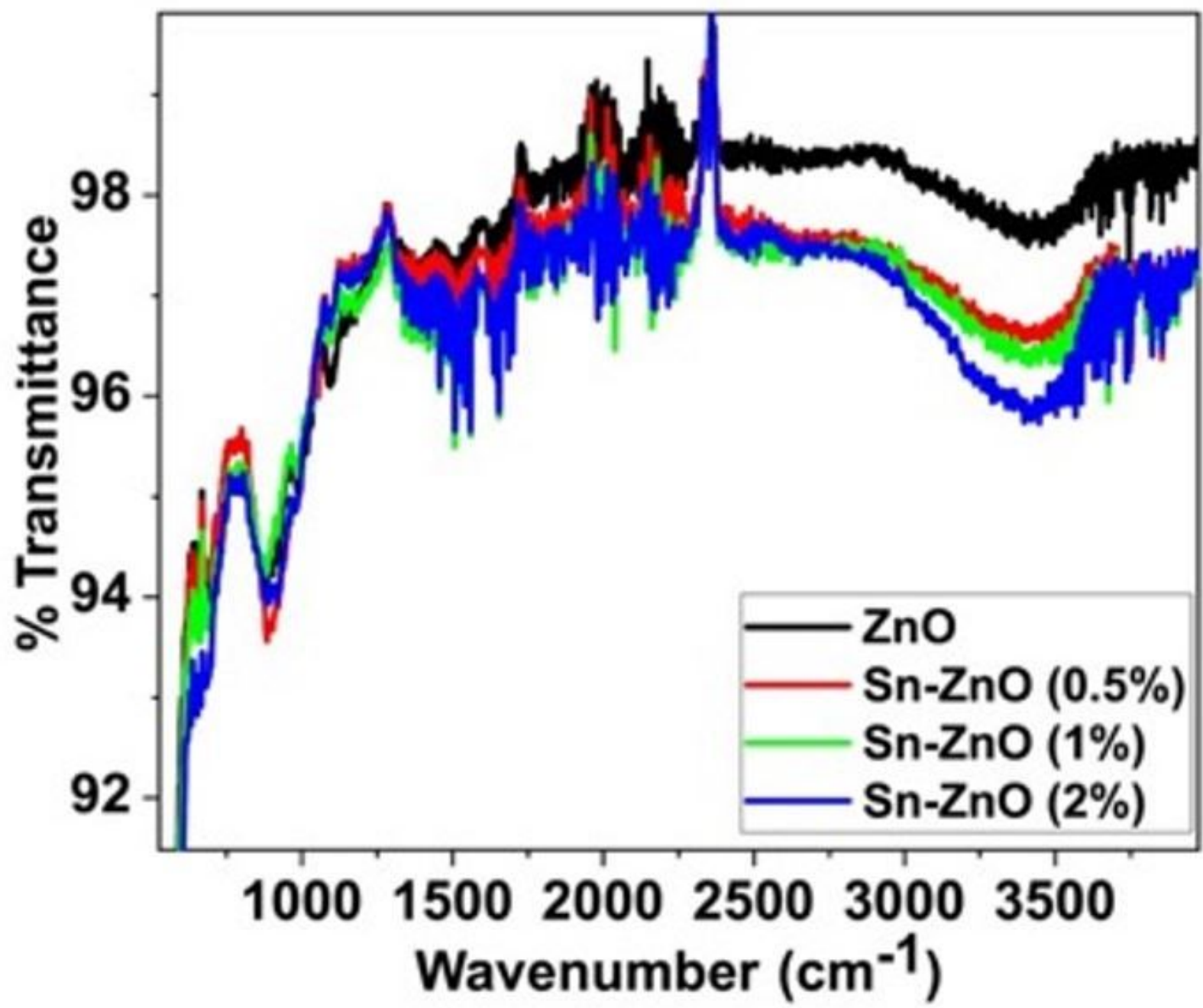

Figure 3

FT-IR spectra of pure and Sn-doped ZnO nanoparticles 

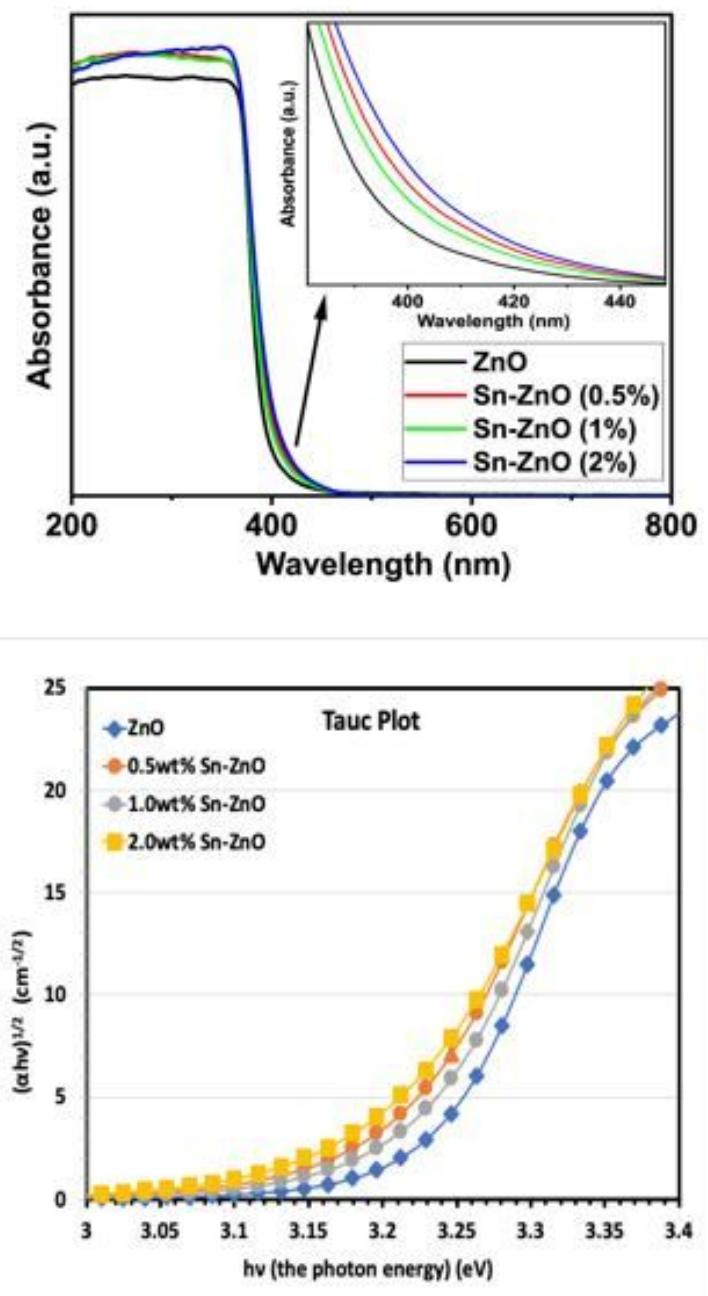

Figure 4

(a) UV-vis absorbance spectra of pure and Sn-doped ZnO nanoparticles, (b) Tauc's plot for optical band gap 

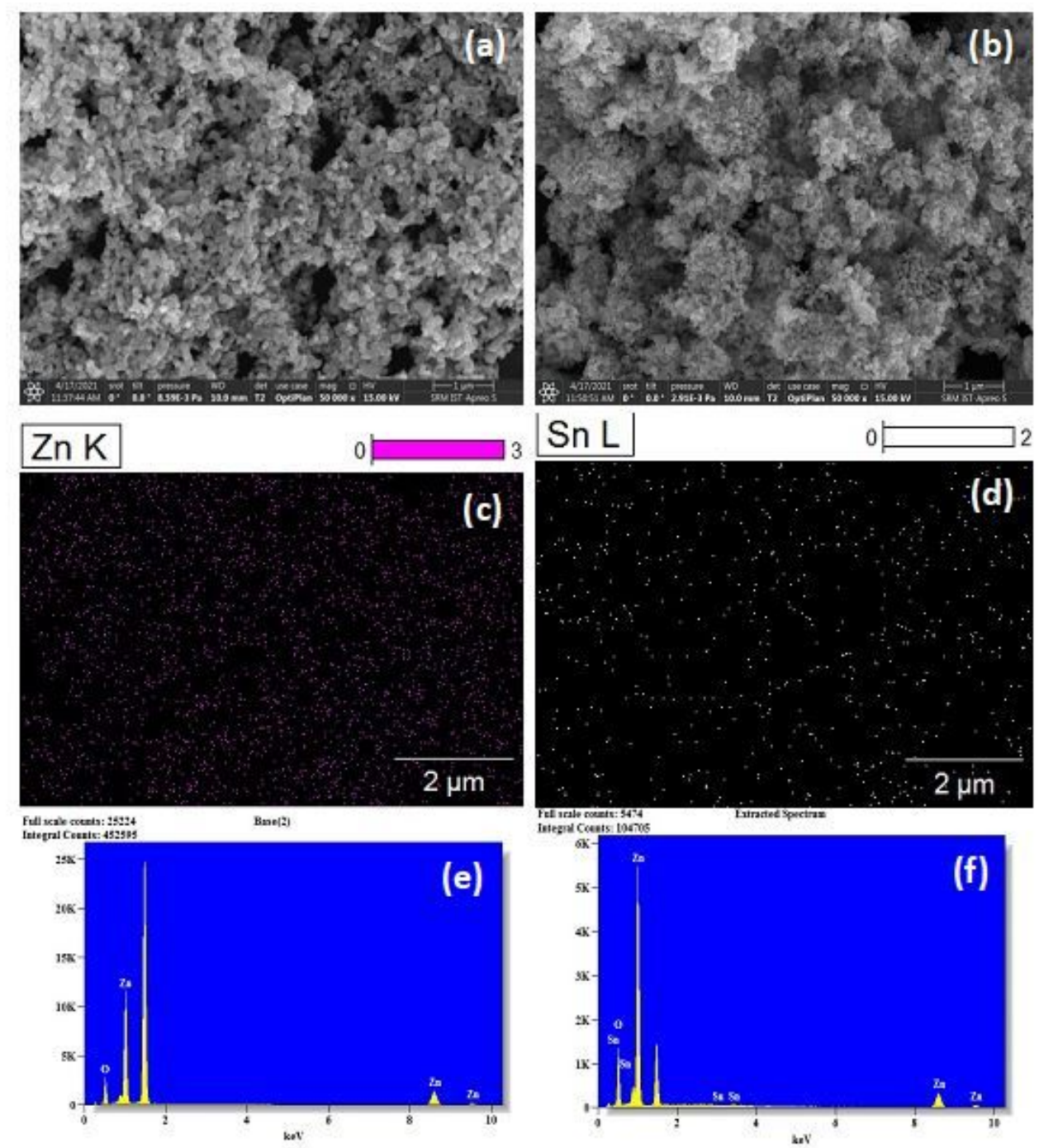

\section{Figure 5}

(a) HR SEM of ZnO, (b) HR SEM of 1 mol\% Sn doped ZnO, (c) Elemental mapping of ZnO, (d) Elemental mapping of $1 \mathrm{~mol} \% \mathrm{Sn}$ doped ZnO, (e) EDS spectra of ZnO and (f) EDS spectra of $1 \mathrm{~mol} \%$ Sn doped ZnO 

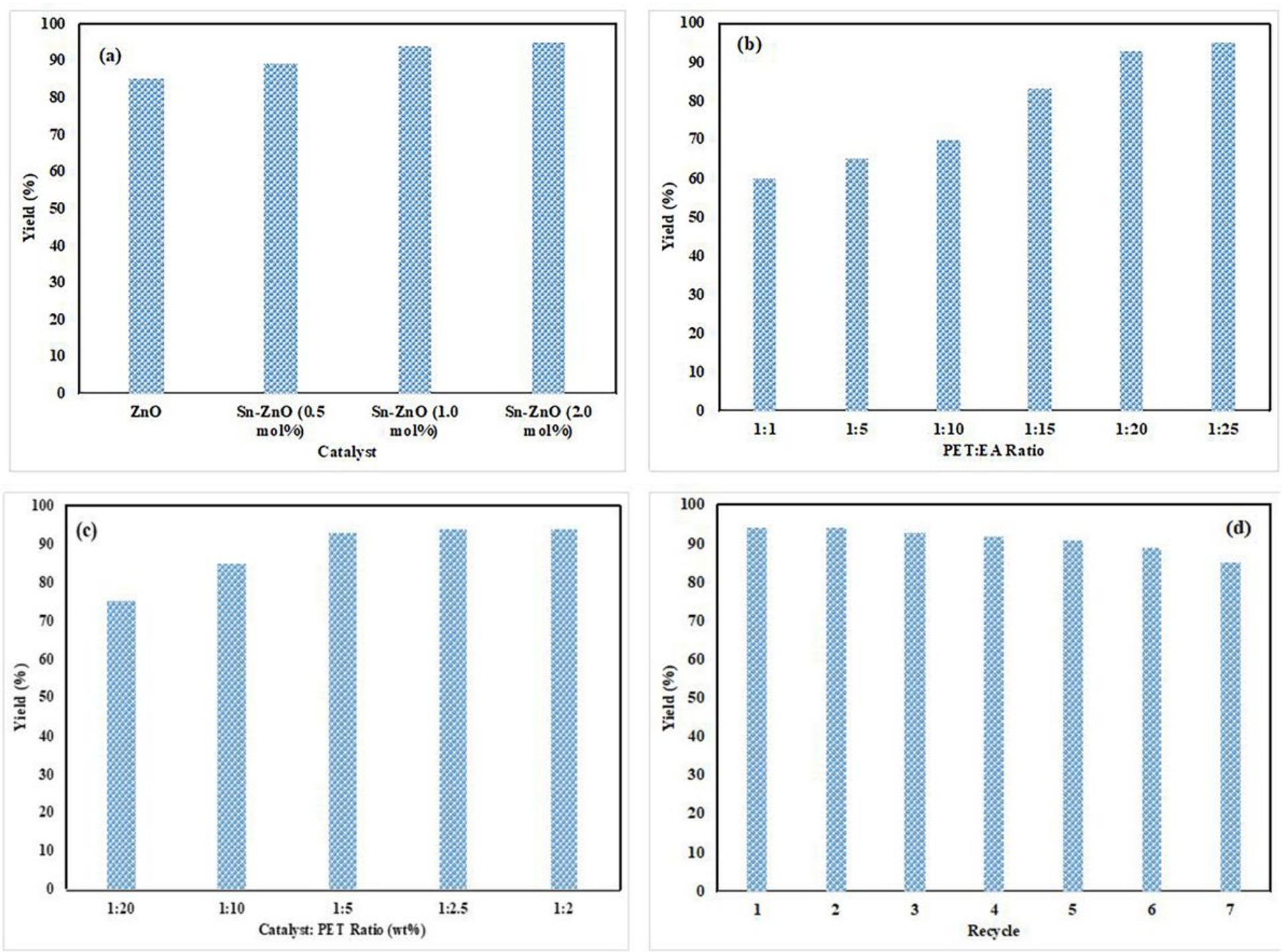

\section{Figure 6}

The aminolysis of PET using Sn doped ZnO nanoparticles and ethanolamine (EA): (a) Yield of BHETA at different Sn doping, (b) Yield of BHETA at PET and EA ratio, (c) Yield of BHETA at catalyst to PET ratio and (d) Catalyst recycling studies

\section{Figure 7}

Structural Characterisation of BHETA (a) ${ }^{1} \mathrm{H}$ NMR, (b) ${ }^{13} \mathrm{C}$ NMR, (c) mass spectrum, (d) FT-IR spectrum and (e) Chemical Structure of BHETA

\section{Supplementary Files}

This is a list of supplementary files associated with this preprint. Click to download.

- SupplementaryInformation.docx

- graphicsabstract.jpg 
- scheme1.jpg

Page 20/20 